\title{
Impact of Social Vulnerability on COVID-19 Incidence and Outcomes in the United States
}

Running Title: Social Vulnerability and the COVID-19 Pandemic in U.S.

Aditi Nayak, MD ${ }^{1}$, Shabatun J. Islam, MD ${ }^{1},{ }^{*}$ Anurag Mehta, MD ${ }^{1},{ }^{*}$ Yi-An Ko, PhD 2 , Shivani A. Patel, MPH, PhD ${ }^{3}$, Abhinav Goyal, MD, MHS ${ }^{1}$, Samaah Sullivan, $\mathrm{PhD}^{3}$, Tené T. Lewis, $\mathrm{PhD}^{3}$, Viola Vaccarino, MD, PhD ${ }^{3}$, Alanna A. Morris, MD¹, MSc, Arshed A. Quyyumi, MD ${ }^{1}$

${ }^{*}$ Dr. Nayak, Dr. Islam and Dr. Mehta contributed equally to this work.

${ }^{1}$ Department of Medicine, Division of Cardiology, Emory University School of Medicine, Atlanta, GA

${ }^{2}$ Department of Biostatistics and Bioinformatics, Rollins School of Public Health, Emory University, Atlanta, GA

${ }^{3}$ Department of Epidemiology, Rollins School of Public Health, Emory University, Atlanta, GA

Date: April 07, 2020

Word Count: 1,167

Tables/Figures: $1 / 2$

References: 14

\section{Address for correspondence:}

Arshed A. Quyyumi, MD

Professor of Medicine, Division of Cardiology

Emory University School of Medicine

Director, Emory Clinical Cardiovascular Research Institute

1462 Clifton Road Northeast, Suite 507

Atlanta, Georgia 30322

Tel: $404-727-3655$

Fax: 404 712-8785

E mail: aquyyum@emory.edu 
medRxiv preprint doi: https://doi.org/10.1101/2020.04.10.20060962; this version posted April 17, 2020. The copyright holder for this preprint

(which was not certified by peer review) is the author/funder, who has granted medRxiv a license to display the preprint in perpetuity.

All rights reserved. No reuse allowed without permission.

\section{KEY POINTS}

\section{Question:}

Is county-level social vulnerability to disasters associated with the case fatality rate (CFR) and incidence of SARS-CoV-2 infection during the COVID-19 pandemic in the U.S.?

\section{Findings:}

Each unit increase in county-level social vulnerability, measured using the Social Vulnerability Index (SVI), was associated with a 63\% higher CFR after adjusting for age and comorbidities. Both CFR and incidence of COVID-19 were significantly higher in counties with lower socioeconomic status and higher proportion of minority populations.

\section{Meaning:}

U.S. counties with higher social vulnerability are experiencing greater mortality rates during the COVID-19 pandemic. 
medRxiv preprint doi: https://doi.org/10.1101/2020.04.10.20060962; this version posted April 17, 2020. The copyright holder for this preprint (which was not certified by peer review) is the author/funder, who has granted medRxiv a license to display the preprint in perpetuity.

All rights reserved. No reuse allowed without permission.

\section{ABSTRACT \\ Importance}

Prior pandemics have disparately affected socially vulnerable communities. Whether regional variations in social vulnerability to disasters influence COVID-19 outcomes and incidence in the U.S. is unknown.

\section{Objective}

To examine the association of Social Vulnerability Index (SVI), a percentile-based measure of county-level social vulnerability to disasters, and its sub-components (socioeconomic status, household composition, minority status, and housing type/transportation accessibility) with the case fatality rate (CFR) and incidence of COVID-19.

\section{Design}

Ecological study of counties with at least 50 confirmed COVID-19 cases as of April $4^{\text {th }}, 2020$. Generalized linear mixed-effects models with state-level clustering were applied to estimate county-level associations of overall SVI and its sub-component scores with COVID-19 CFR (deaths/100 cases) and incidence (cases/1000 population), adjusting for population percentage aged $\geq 65$ years, and for comorbidities using the average Hierarchical Condition Category (HCC) score. Counties with high SVI ( $\geq$ median) and high CFR ( $\geq$ median) were identified.

\section{Setting}

Population-based study of U.S. county-level data.

\section{Participants}

U.S. counties with at least 50 confirmed COVID-19 cases.

\section{Main outcomes and measures}

COVID-19 CFR and incidence.

\section{Results}

Data from 433 counties including 283,256 cases and 6,644 deaths were analyzed. Median SVI was 0.46 [Range: $0.01-1.00]$, and median CFR and incidence were $1.9 \%$ [Range: $0-13.3$ ] and 
medRxiv preprint doi: https://doi.org/10.1101/2020.04.10.20060962; this version posted April 17, 2020. The copyright holder for this preprint (which was not certified by peer review) is the author/funder, who has granted medRxiv a license to display the preprint in perpetuity.

All rights reserved. No reuse allowed without permission.

1.2 per 1000 people [Range: 0.6-38.8], respectively. Higher SVI, indicative of greater social vulnerability, was associated with higher CFR (RR: $1.19[1.05,1.34], p=0.005$, per-1 unit increase), an association that strengthened after adjustment for age $\geq 65$ years and comorbidities (RR: $1.63[1.38,1.91], p<0.001)$, and was further confirmed in a sensitivity analysis limited to six states with the highest testing levels. Although the association between overall SVI and COVID19 incidence was not significant, the SVI sub-components of socioeconomic status and minority status were both predictors of higher incidence and CFR. A combination of high SVI $(\geq 0.46)$ and high adjusted CFR ( $\geq 2.3 \%$ ) was observed in $28.9 \%$ of counties.

\section{Conclusions and Relevance}

Social vulnerability is associated with higher COVID-19 case fatality. High social vulnerability and CFR coexist in more than 1 in 4 U.S. counties. These counties should be targeted by public policy interventions to help alleviate the pandemic burden on the most vulnerable population.

\section{Abstract Word Count: 349}

Key Words: Coronavirus; SARS-CoV-2; Pandemic; Outcomes; Socioeconomic status 
medRxiv preprint doi: https://doi.org/10.1101/2020.04.10.20060962; this version posted April 17, 2020. The copyright holder for this preprint (which was not certified by peer review) is the author/funder, who has granted medRxiv a license to display the preprint in perpetuity.

All rights reserved. No reuse allowed without permission.

\section{Introduction}

Community-level social disadvantage and vulnerability to disasters can influence the incidence of COVID-19 and its adverse outcomes in several ways. For example, lower socioeconomic status (SES) is associated with poor healthcare access, which may increase risk for adverse outcomes. ${ }^{1}$ Labor inequalities, lack of workplace protections, and household overcrowding may decrease the ability to adhere to social-distancing guidelines. ${ }^{2}$ Additionally, race-ethnic minorities and immigrants are less likely to have access to appropriate and timely healthcare. ${ }^{3}$ Evidence suggests that these inequalities contributed to disease spread and severity during the H1N1 influenza pandemic. ${ }^{4}$

Real-time evaluation of the impact of community-level social vulnerability on disease incidence and adverse outcomes during the ongoing COVID-19 pandemic is important to guide public health policy and healthcare resource allocation in the U.S. The Social Vulnerability Index (SVI), created and maintained by the Geospatial Research, Analysis, and Services Program (GRASP) at the Centers for Disease Control and Prevention (CDC) and Agency for Toxic Substances and Disease Registry, is a percentile-based index of county-level vulnerability to disasters. ${ }^{5,6}$ Herein, we report the association of SVI with COVID-19 case-fatality rates (CFR) and incidence in the U.S.

\section{Methods}

County-level data on COVID-19 CFR (deaths per 100 confirmed COVID-19 cases) and incidence (cases per 1000 population) for U.S. counties with at least 50 cases $(n=433)$ were obtained from the Johns Hopkins Center for Systems Science and Engineering database on April $4^{\text {th }}, 2020 .{ }^{7}$ County-level SVI data for 2018 were obtained from the CDC GRASP database. ${ }^{8}$ As a proxy for county-level medical comorbidity, we utilized Hierarchical Condition Category (HCC) risk scores acquired from the Centers for Medicare and Medicaid Services (CMS), which are based on medical risk profiles and demographics of county Medicare beneficiaries. ${ }^{9,10}$ 
medRxiv preprint doi: https://doi.org/10.1101/2020.04.10.20060962; this version posted April 17, 2020. The copyright holder for this preprint (which was not certified by peer review) is the author/funder, who has granted medRxiv a license to display the preprint in perpetuity.

All rights reserved. No reuse allowed without permission.

Generalized linear mixed models, with negative binomial distribution or Poisson distribution when appropriate, ${ }^{11}$ were used to examine the association of outcomes with SVI (reported as percentile of social vulnerability, with higher numbers representing increased vulnerability) and its sub-components including socioeconomic status, household composition, minority status, and housing type/transportation accessibility (Supplement). ${ }^{5,6}$ Given differences in COVID-19 testing by state, state-specific random intercepts were incorporated in models to account for correlations among counties within the same state. Covariates included percentage of population aged $\geq 65$ years and average HCC score. A sensitivity analysis was conducted using data from six states (New York, New Jersey, Washington, Massachusetts, Vermont, and Louisiana) with the highest levels of testing as of April $4^{\text {th }}, 2020 .{ }^{12}$ Age- and HCC score-adjusted CFR and incidence were compared across medians of overall SVI using one-way ANOVA. Lastly, we identified counties with high SVI ( $\geq$ median) and high adjusted CFR ( $\geq$ median) as potential targets for public policy interventions. Statistical analyses were performed using $R$ version 3.6.1 (R Foundation for Statistical Computing, Vienna, Austria).

\section{Results}

Of 3,142 counties in the U.S., 433 had $>50$ COVID-19 confirmed cases, accounting for 283,256 cases and 6,644 deaths as of April $4^{\text {th }}, 2020$. The median SVI was 0.46 [Range: $0.01-1.0$ ], CFR was $1.9 \%$ [Range: $0-13.3$ ], and incidence was 1.2 per 1000 people [Range: $0.6-38.8$ ].

There was a significant association between overall SVI and CFR (RR: 1.19 [1.05, 1.34], $\mathrm{p}=0.005$ per-1 unit increase in SVI) that was strengthened after adjustment for percentage of population aged $\geq 65$ years and comorbidities using the county HCC score (RR: 1.63 [1.38, 1.91], $p<0.001$ ) (Table 1). Sensitivity analysis of six states with the highest levels of testing $(n=99$ counties, cases $=173,612$, deaths $=4,122)$ confirmed strong associations between overall SVI and the CFR (RR: $2.58[2.09,3.18], p<0.001)$. In the overall study sample, adjusted CFR was significantly higher in counties with greater vulnerability $(S V I<$ median: $2.18 \pm 0.90$ vs. 
medRxiv preprint doi: https://doi.org/10.1101/2020.04.10.20060962; this version posted April 17, 2020. The copyright holder for this preprint (which was not certified by peer review) is the author/funder, who has granted medRxiv a license to display the preprint in perpetuity.

All rights reserved. No reuse allowed without permission.

$\geq$ median: $2.63 \pm 0.99 ; p<0.001)$, Figure 1. Of the SVI sub-components, socioeconomic status was associated with 2.6-fold, minority status/language with 1.6-fold, and housing type/transport accessibility with 1.9-fold higher CFR in adjusted models (Table 1).

There was a nominal association between overall SVI and the incidence (RR: 1.30 [0.96, 1.77], $p=0.09$ ) that became insignificant after covariate adjustment (Table 1). Thus, the adjusted incidence was similar in counties stratified by the overall SVI (<median:1.10 \pm 0.95 vs. $\geq$ median: $1.25 \pm 1.11 ; p=0.15)$, Figure 1. However, two sub-components of the SVI, including socioeconomic status (1.6-fold) and minority status/language (2-fold) were associated with higher incidence in adjusted models (Table 1).

In the overall study sample, a combination of high SVI $(\geq 0.46)$ and high adjusted CFR ( $\geq 2.3 \%$ ) was observed in 125 counties (28.9\%, Table S1), while 124 counties $(28.6 \%)$ had SVI and adjusted CFR below respective medians (Figure 2).

\section{Discussion}

Using county-level data and after accounting for state-level clustering, age, and comorbidities, we show that greater social vulnerability is associated with higher COVID-19related CFR during the first several weeks of the ongoing pandemic in the U.S. This association is driven by lower socioeconomic status, higher minority population prevalence, and poor housing conditions and transport accessibility in these counties. Although the overall SVI was not associated with COVID-19 incidence, it is evident that the incidence is higher in counties with lower socioeconomic status and with greater proportion of minority population.

Our findings are supported by the conceptual model of Blumenshine and colleagues which posits that differences in social position can affect outcomes during pandemics. ${ }^{13}$ Social vulnerability, captured here as socioeconomic status, proportion of minority population, and poor housing conditions, contribute to disparities in both exposure and treatment access, which synergistically contribute to adverse outcomes. Despite earlier calls to address social vulnerabilities in order to reduce adverse outcomes proactively, these disparities were evident 
during the $2009 \mathrm{H} 1 \mathrm{~N} 1$ pandemic, ${ }^{4,13}$ and more than a decade later, continue to account for worse outcomes in vulnerable communities during the COVID-19 pandemic.

More than a quarter of the counties studied, that are located in 22 states with countylevel clustering in Louisiana, Georgia, Michigan, Illinois, and California (Table S1), had both high social vulnerability and high adjusted CFR. Given the direct association of SVI with CFR, these counties represent COVID-19 'hot-spots' where healthcare resource allocation is urgently needed. Unaddressed, an ensuing "disease-driven poverty trap", a vicious cycle of disease and worsening social disparity, could have devastating effects in these counties. ${ }^{14}$

A major limitation of the study is our inability to account for the contribution of countylevel COVID-19 testing. However, in sensitivity analyses that included states with the highest level of testing, we observed similar associations. In addition, we have only included 433 $(13.8 \%)$ U.S. counties in our report, but these counties represent the breadth of existing social vulnerability.

This important and timely report demonstrates associations between social vulnerability to disaster and adverse outcomes in the evolving stages of the COVID-19 pandemic in the U.S. Our findings can help guide public policy interventions and resource allocations to improve outcomes in vulnerable communities. 
medRxiv preprint doi: https://doi.org/10.1101/2020.04.10.20060962; this version posted April 17, 2020. The copyright holder for this preprint (which was not certified by peer review) is the author/funder, who has granted medRxiv a license to display the preprint in perpetuity.

All rights reserved. No reuse allowed without permission.

\section{FIGURE LEGEND}

Figure 1. Incidence and Case Fatality Rates of COVID-19 by high ( $\geq$ median) and low (<median) overall Social Vulnerability Index (SVI) after adjusting for percentage of population age $\geq 65$ years and CMS average Hierarchical Condition Category (HCC) score (proxy for comorbidity).

Figure 2. U.S. Map depicting counties ( $n=433)$ stratified by median SVI and adjusted CFR. High SVI and adjusted CFR observed in 125 counties, high SVI or adjusted CFR observed in 184 counties, and low SVI and adjusted CFR observed in 124 counties. 


\section{ACKNOWLEDGEMENTS}

None

\section{SOURCES OF FUNDING}

S.J.I. is supported by NIH grants T32 HL130025 and T32 HL007745-26A1. A.M. is supported by American Heart Association grant 19POST34400057 and the Abraham J. \& Phyllis Katz

Foundation. S.S. is supported by NIH grants K12HD085850 \& L30HL148912. A.A.M. is

supported by funding from NIH/NHLBI K23 HL124287 and the Robert Wood Johnson

Foundation (Harold Amos Medical Faculty Development Program). A.A.Q. is supported by NIH grants 1P20HL113451-01, 1R61HL138657-02, 1P30DK111024-03S1, 5R01HL095479-08, 3RF1AG051633-01S2, 5R01AG042127-06, 2P01HL086773-08, U54AG062334-01, 1R01HL141205-01, 5P01HL101398-02, 1P20HL113451-01, 5P01HL086773-09

1RF1AG051633-01, R01 NS064162-01, R01 HL89650-01, HL095479-01, 1DP3DK094346-01, 2P01HL086773, and American Heart Association grant 15SFCRN23910003.

\section{DISCLOSURES}

The authors have no conflicts of interest to disclose. 
medRxiv preprint doi: https://doi.org/10.1101/2020.04.10.20060962; this version posted April 17, 2020. The copyright holder for this preprint (which was not certified by peer review) is the author/funder, who has granted medRxiv a license to display the preprint in perpetuity.

All rights reserved. No reuse allowed without permission.

\section{REFERENCES}

1. Link BG. Epidemiological sociology and the social shaping of population health. Journal of health and social behavior. 2008;49(4):367-384.

2. Drago R, Miller K. Sick at work: infected employees in the workplace during the H1N1 pandemic. Institute for Women's Policy Research. 2010(B264).

3. Leclere FB, Jensen L, Biddlecom AE. Health care utilization, family context, and adaptation among immigrants to the United States. Journal of health and social behavior. 1994:370-384.

4. Quinn SC, Kumar S, Freimuth VS, Musa D, Casteneda-Angarita N, Kidwell K. Racial disparities in exposure, susceptibility, and access to health care in the US H1N1 influenza pandemic. American journal of public health. 2011;101(2):285-293.

5. Flanagan B, Hallisey E, Adams E, Lavery A. Measuring community vulnerability to natural and anthropogenic hazards: The Centers for Disease Control and Prevention's social vulnerability index. Journal of Environmental Health. 2018;80:34-36.

6. Flanagan BE, Gregory EW, Hallisey EJ, Heitgerd JL, Lewis B. A social vulnerability index for disaster management. Journal of homeland security and emergency management. 2011;8(1).

7. Dong E, Du H, Gardner L. An interactive web-based dashboard to track COVID-19 in real time. The Lancet Infectious Diseases. DOI:https://doi.org/10.1016/S14733099(20)30120-1

8. Centers for Disease Control and Prevention/Agency for Toxic Substances and Disease Registry/ Geospatial Research, Analysis, and Services Program. Social Vulnerability Index 2018 Database US. https://svi.cdc.gov/data-and-tools-download.html. Accessed on April 2, 2020.

9. Li P, Kim MM, Doshi JA. Comparison of the performance of the CMS Hierarchical Condition Category (CMS-HCC) risk adjuster with the Charlson and Elixhauser 
comorbidity measures in predicting mortality. BMC health services research. 2010;10(1):245.

10. Centers for Medicare Medicaid Services. Medicare data for the geographic variation public use file: a methodological overview. https://www.cms.gov/Research-StatisticsData-and-Systems/Statistics-Trends-and-Reports/Medicare-GeographicVariation/Downloads/Geo_Var_PUF_Methods_Paper.pdf. Accessed on April 1, 2020.

11. McCullagh P, Nedler JA. Generalized linear models. $2^{\text {nd }}$ Ed. Routledge; 2018.

12. Madrigal A. The COVID Tracking Project. https://covidtracking.com. Accessed April 4, 2020.

13. Blumenshine P, Reingold A, Egerter S, Mockenhaupt R, Braveman P, Marks J. Pandemic influenza planning in the United States from a health disparities perspective. Emerg Infect Dis. 2008;14(5):709-715.

14. Bonds MH, Keenan DC, Rohani P, Sachs JD. Poverty trap formed by the ecology of infectious diseases. Proceedings of the Royal Society B: Biological Sciences. 2010;277(1685):1185-1192. 
Table 1. Association of Social Vulnerability Index and its sub-components with case fatality rate and incidence of COVID-19 in the U.S. Risk ratio per-1 unit increase in respective score (indicating greater social vulnerability) is shown

\begin{tabular}{|c|c|c|c|c|c|c|}
\hline & \multicolumn{2}{|l|}{ Model 1} & \multicolumn{2}{|l|}{ Model 2} & \multicolumn{2}{|l|}{ Model 3} \\
\hline & $\begin{array}{c}\text { Risk Ratio } \\
\text { (95\% Cl) }\end{array}$ & P-value & $\begin{array}{c}\text { Risk Ratio } \\
\text { (95\% Cl) }\end{array}$ & P-value & $\begin{array}{c}\text { Risk Ratio } \\
\text { (95\% Cl) }\end{array}$ & P-value \\
\hline \multicolumn{7}{|c|}{ Case Fatality Rate } \\
\hline Overall Social Vulnerability Index & $1.19(1.05,1.34)$ & 0.005 & - & - & $1.63(1.38,1.91)$ & $<0.001$ \\
\hline Socioeconomic Status & $1.56(1.37,1.77)$ & $<0.001$ & $1.73(1.51,1.98)$ & $<0.001$ & $2.59(2.20,3.07)$ & $<0.001$ \\
\hline Minority Status \& Language & $1.08(0.86,1.36)$ & 0.52 & $1.39(1.07,1.82)$ & 0.01 & $1.55(1.18,2.07)$ & 0.002 \\
\hline Housing Type \& Transport & $1.44(1.28,1.62)$ & $<0.001$ & $1.65(1.46,1.88)$ & $<0.001$ & $1.86(1.63,2.14)$ & $<0.001$ \\
\hline Household Composition \& Disability & $0.83(0.72,0.96)$ & 0.01 & - & - & $0.88(0.74,1.01)$ & 0.08 \\
\hline \multicolumn{7}{|c|}{ Incidence } \\
\hline Overall Social Vulnerability Index & $1.30(0.96,1.77)$ & 0.09 & - & - & $1.30(0.95,1.78)$ & 0.21 \\
\hline Socioeconomic Status & $1.50(1.08,2.09)$ & 0.01 & $1.54(1.11,2.15)$ & 0.01 & $1.60(1.17,2.20)$ & 0.03 \\
\hline Minority Status \& Language & $1.68(1.11,2.53)$ & 0.01 & $2.04(1.30,3.18)$ & 0.02 & $1.97(1.44,2.70)$ & 0.006 \\
\hline Housing Type \& Transport & $1.26(0.95,1.66)$ & 0.11 & $1.30(0.99,1.72)$ & 0.07 & $1.24(0.90,1.70)$ & 0.18 \\
\hline Household Composition \& Disability & $0.97(0.71,1.33)$ & 0.85 & - & - & $0.88(0.65,1.21)$ & 0.50 \\
\hline
\end{tabular}

Model 1: Unadjusted generalized linear mixed-effects model accounting for state-level clustering.

Model 2: Model 1+ adjusted for percentage of population age $\geq 65$; percentage age $\geq 65$ not included as covariates for models for overall Social Vulnerability Index and Household Composition because these indices contain this variable.

Model 3: Model 2+ CMS average Hierarchical Condition Category (HCC) score (proxy for comorbidity) 
Figure 1. Incidence and Case Fatality Rates of COVID-19 by high ( $\geq$ median) and low (<median) overall Social Vulnerability Index (SVI) after adjusting for percentage of population age $\geq 65$ years and CMS average Hierarchical Condition Category (HCC) score (proxy for comorbidity).
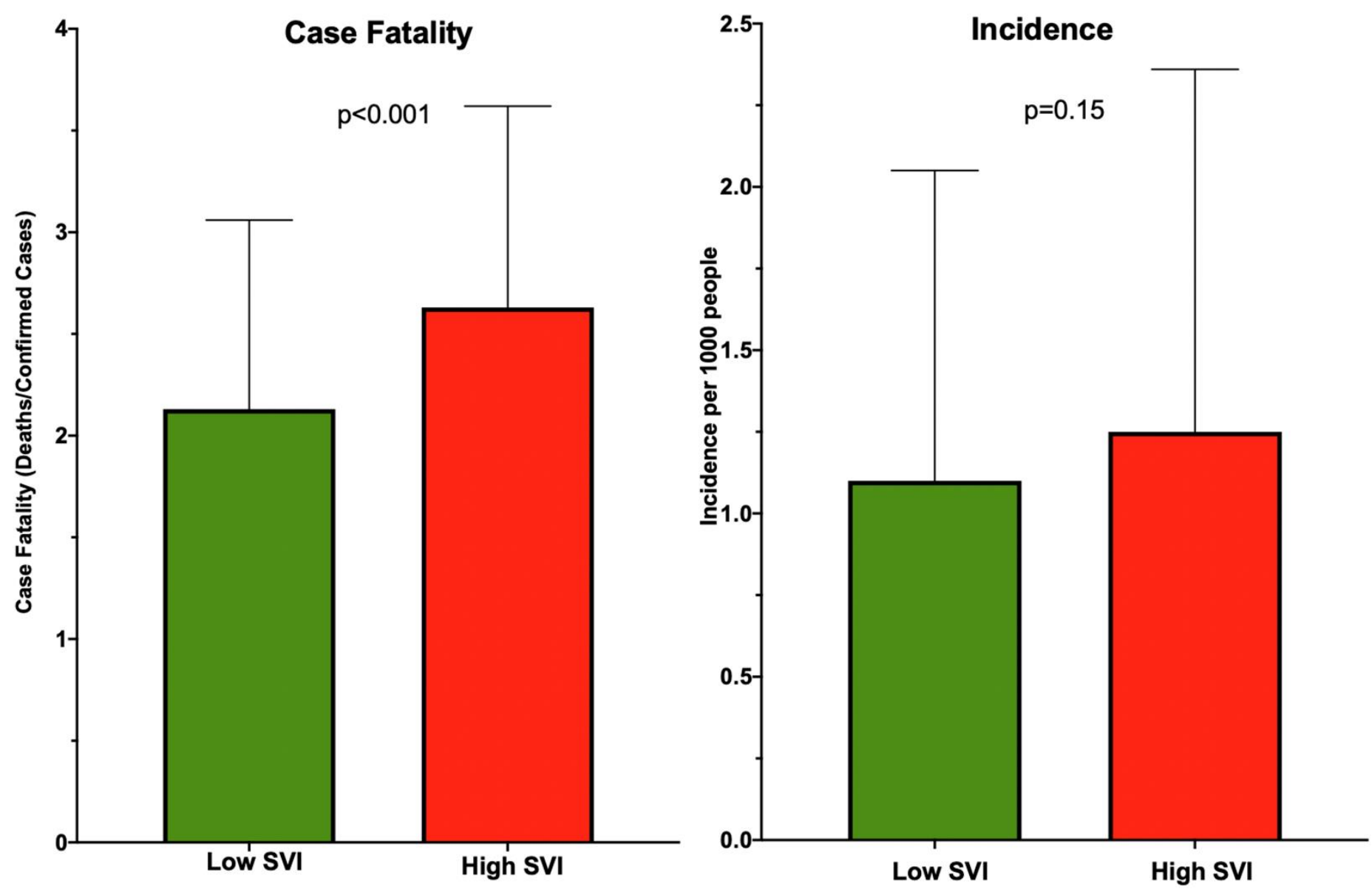
Figure 2. U.S. Map depicting counties $(n=433)$ stratified by median SVI and adjusted CFR. High SVI and CFR observed in 125 counties, high SVI or CFR observed in 184 counties, and low SVI and CFR observed in 124 counties.

\section{Counties with High SVI and High CFR ( $n=125)$}

Counties with either High SVI or High CFR $(n=184)$

Counties with Low SVI and Low CFR $(n=124)$

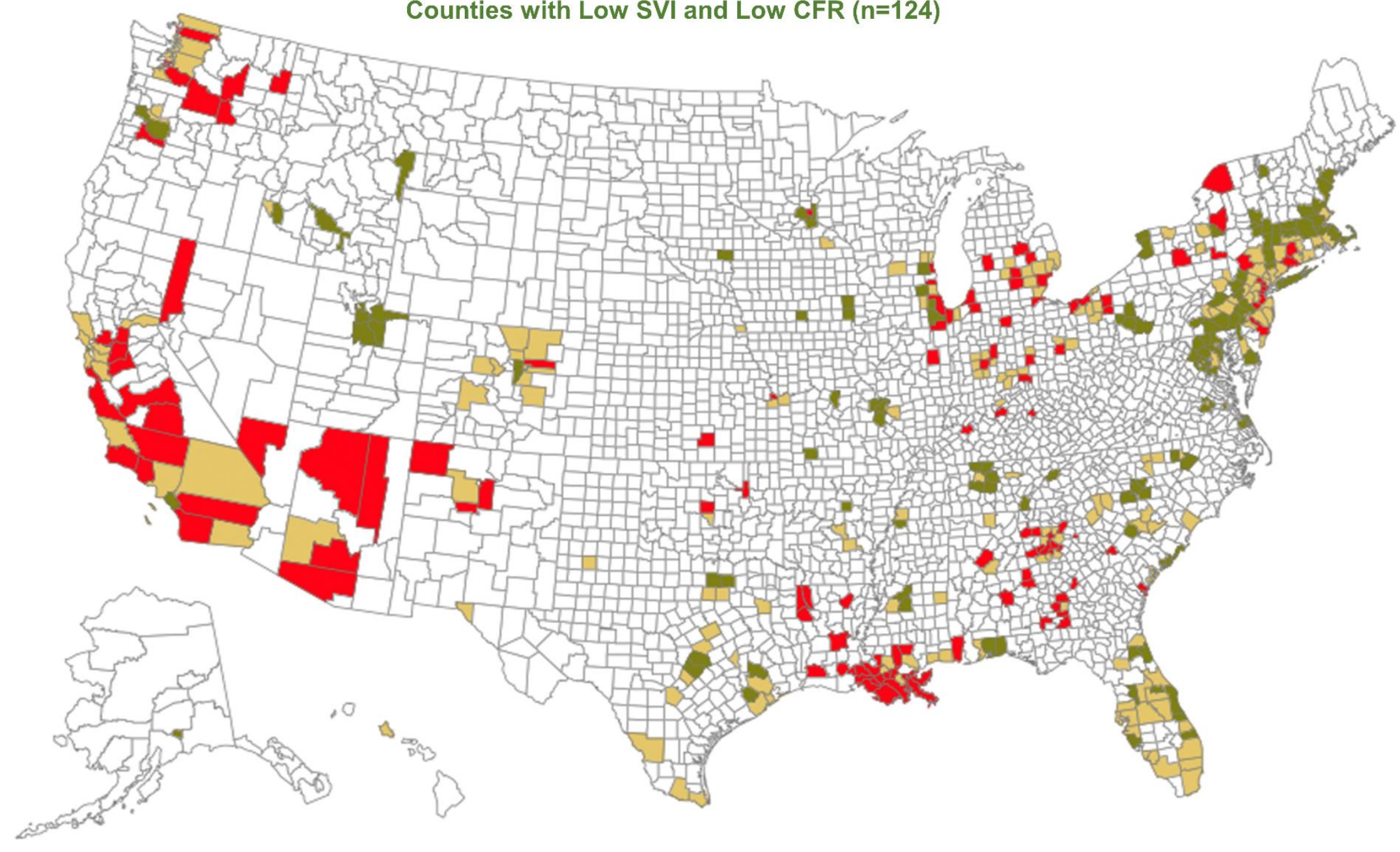




\section{SUPPLEMENTAL MATERIAL}

\section{Impact of Social Vulnerability on COVID-19 Incidence and Outcomes in the United States}

Running Title: Social Vulnerability and the COVID-19 Pandemic in U.S.

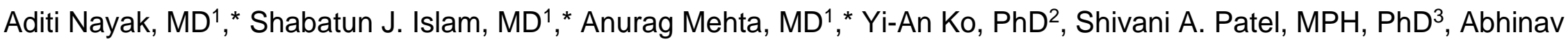
Goyal, MD, MHS ${ }^{1}$, Samaah Sullivan, $\mathrm{PhD}^{3}$, Tené T. Lewis, $\mathrm{PhD}^{3}$, Viola Vaccarino, MD, PhD ${ }^{3}$, Alanna A. Morris, $\mathrm{MD}^{1}$, MSc, Arshed A. Quyyumi, MD ${ }^{1}$

${ }^{*}$ Dr. Nayak, Dr. Islam and Dr. Mehta contributed equally to this work.

${ }^{1}$ Department of Medicine, Division of Cardiology, Emory University School of Medicine, Atlanta, GA

${ }^{2}$ Department of Biostatistics and Bioinformatics, Rollins School of Public Health, Emory University, Atlanta, GA

${ }^{3}$ Department of Epidemiology, Rollins School of Public Health, Emory University, Atlanta, GA 


\section{Social Vulnerability Index}

The social vulnerability index (SVI) is a measure of community resilience to stresses on human health such as disease outbreaks and natural or human-caused disasters. ${ }^{5,6}$ The SVI database and mapping tool has been created by the Geospatial Research, Analysis, and Services Program (GRASP) at the Centers for Disease Control and Prevention (CDC)/Agency for Toxic Substances and Disease Registry. The index helps public health officials and emergency response planners to identify and map communities that are likely to need support before, during, and after a disaster. The SVI uses statistical data from the U.S. Census on 15 variables to determine social vulnerability. These 15 variables are grouped together into four related themes as described below. Each of these variables are ranked from highest to lowest vulnerability across census tracts in the U.S. and a percentile rank is calculated for each variable, theme, and the overall SVI. We have used the 2018 SVI data at the county level in the current analysis. ${ }^{3}$ 


\begin{tabular}{|l|l|}
\hline Socioeconomic Status & $\begin{array}{l}\text { Below Poverty } \\
\text { Unemployed } \\
\text { Income } \\
\text { No High School Diploma }\end{array}$ \\
\hline Household composition and Disability & $\begin{array}{l}\text { Age 65 years or older } \\
\text { Age 17 years or younger } \\
\text { Older than Age 5 years with a Disability }\end{array}$ \\
\hline Minority Status and Language & $\begin{array}{l}\text { Minority } \\
\text { Speak English "Less than Well" }\end{array}$ \\
\hline Housing Type and Transportation & Multi-Unit Structures \\
& Mobile Homes \\
Crowding \\
No Vehicle \\
Group Quarters
\end{tabular}


Table S1. Counties with high Social Vulnerability Index ( $\geq$ median, 0.46$)$ and high Adjusted Case Fatality Rate ( $\geq$ median, $2.3 \%)$

\begin{tabular}{|l|l|l|l|l|l|l|}
\hline \multicolumn{1}{|c|}{ State } & County & \multicolumn{1}{|c|}{$\begin{array}{c}\text { Area } \\
(\text { Square } \\
\text { miles })\end{array}$} & population & $\begin{array}{c}\text { Total } \\
\text { Incidence } \\
\text { per 1000 }\end{array}$ & $\begin{array}{c}\text { Adjusted } \\
\text { Case } \\
\text { Fatality } \\
\text { Rate }\end{array}$ & $\begin{array}{c}\text { Social } \\
\text { Vulnerability } \\
\text { Index }\end{array}$ \\
\hline ALABAMA & Chambers & 596.56 & 33826 & 0.77 & 2.99 & 0.74 \\
\hline ALABAMA & Jefferson & 1111.38 & 659892 & 0.75 & 2.88 & 0.66 \\
\hline ALABAMA & Lee & 607.55 & 159287 & 0.75 & 3.20 & 0.66 \\
\hline ALABAMA & Mobile & 1229.37 & 414659 & 0.77 & 2.87 & 0.75 \\
\hline ALABAMA & Montgomery & 785.30 & 226941 & 0.79 & 3.14 & 0.84 \\
\hline ARIZONA & Coconino & 18618.67 & 140217 & 0.88 & 2.70 & 0.71 \\
\hline ARIZONA & Navajo & 9949.88 & 108705 & 0.95 & 2.67 & 1.00 \\
\hline ARIZONA & Pima & 9187.22 & 1019722 & 0.92 & 2.72 & 0.88 \\
\hline ARIZONA & Pinal & 5365.84 & 419721 & 0.92 & 2.42 & 0.86 \\
\hline CALIFORNIA & Fresno & 5958.10 & 978130 & 0.35 & 2.76 & 0.96 \\
\hline
\end{tabular}




\begin{tabular}{|c|c|c|c|c|c|c|}
\hline CALIFORNIA & Kern & 8132.26 & 883053 & 0.35 & 2.49 & 0.97 \\
\hline CALIFORNIA & Monterey & 3281.72 & 433212 & 0.33 & 3.16 & 0.80 \\
\hline CALIFORNIA & Riverside & 7206.56 & 2383286 & 0.33 & 2.51 & 0.79 \\
\hline CALIFORNIA & Sacramento & 965.44 & 1510023 & 0.33 & 2.44 & 0.73 \\
\hline CALIFORNIA & San Diego & 4208.76 & 3302833 & 0.31 & 2.41 & 0.56 \\
\hline CALIFORNIA & San Joaquin & 1392.39 & 732212 & 0.34 & 2.71 & 0.89 \\
\hline CALIFORNIA & $\begin{array}{l}\text { Santa } \\
\text { Barbara }\end{array}$ & 2735.14 & 443738 & 0.33 & 2.98 & 0.71 \\
\hline CALIFORNIA & Santa Cruz & 445.12 & 273765 & 0.31 & 3.05 & 0.54 \\
\hline CALIFORNIA & Solano & 821.75 & 438530 & 0.32 & 2.53 & 0.59 \\
\hline CALIFORNIA & Stanislaus & 1496.02 & 539301 & 0.34 & 2.60 & 0.87 \\
\hline CALIFORNIA & Tulare & 4824.38 & 460477 & 0.35 & 2.65 & 0.94 \\
\hline CALIFORNIA & Ventura & 1842.47 & 848112 & 0.31 & 2.40 & 0.48 \\
\hline COLORADO & Adams & 1166.26 & 497115 & 1.66 & 2.51 & 0.59 \\
\hline CONNECTICUT & Hartford & 734.96 & 894730 & 1.05 & 3.03 & 0.52 \\
\hline CONNECTICUT & New Haven & 604.52 & 859339 & 1.06 & 3.00 & 0.52 \\
\hline
\end{tabular}




\begin{tabular}{|l|l|l|l|l|l|l|}
\hline GEORGIA & Bartow & 459.52 & 103620 & 1.42 & 3.27 & 0.59 \\
\hline GEORGIA & Carroll & 499.03 & 116022 & 1.49 & 4.05 & 0.78 \\
\hline GEORGIA & Chatham & 433.12 & 287049 & 1.46 & 3.88 & 0.69 \\
\hline GEORGIA & Clarke & 119.22 & 124602 & 1.49 & 3.96 & 0.77 \\
\hline GEORGIA & Clayton & 141.67 & 278666 & 1.55 & 3.08 & 0.91 \\
\hline GEORGIA & DeKalb & 267.73 & 743187 & 1.45 & 3.38 & 0.66 \\
\hline GEORGIA & Dougherty & 328.64 & 91049 & 1.56 & 3.55 & 0.95 \\
\hline GEORGIA & Douglas & 200.10 & 141840 & 1.40 & 2.95 & 0.54 \\
\hline GEORGIA & Early & 512.60 & 10348 & 1.55 & 4.26 & 0.92 \\
\hline GEORGIA & Floyd & 509.82 & 96824 & 1.54 & 3.83 & 0.89 \\
\hline GEORGIA & Fulton & 526.74 & 1021902 & 1.40 & 3.36 & 0.53 \\
\hline GEORGIA & Hall & 392.98 & 195961 & 1.45 & 3.82 & 0.66 \\
\hline GEORGIA & Houston & 376.06 & 151682 & 1.41 & 3.23 & 0.57 \\
\hline GEORGIA & Mitchell & 512.16 & 22432 & 1.58 & 3.62 & 0.99 \\
\hline GEORGIA & Richmond & 324.32 & 201463 & 1.55 & 3.98 & 0.93 \\
\hline GEORGIA & Rockdale & 129.81 & 89011 & 1.41 & 3.51 & 0.55 \\
\hline
\end{tabular}




\begin{tabular}{|c|c|c|c|c|c|c|}
\hline GEORGIA & Sumter & 482.87 & 30352 & 1.57 & 3.44 & 0.98 \\
\hline GEORGIA & Terrell & 335.74 & 8859 & 1.56 & 3.62 & 0.96 \\
\hline ILLINOIS & Champaign & 996.11 & 209448 & 0.68 & 2.46 & 0.50 \\
\hline ILLINOIS & Cook & 944.93 & 5223719 & 0.71 & 2.34 & 0.68 \\
\hline ILLINOIS & Kankakee & 676.50 & 111061 & 0.71 & 2.40 & 0.67 \\
\hline INDIANA & Allen & 657.32 & 370016 & 1.05 & 2.79 & 0.52 \\
\hline INDIANA & Lake & 498.82 & 486849 & 1.11 & 2.61 & 0.73 \\
\hline INDIANA & Madison & 451.92 & 129505 & 1.10 & 2.70 & 0.67 \\
\hline INDIANA & Marion & 396.44 & 944523 & 1.13 & 2.74 & 0.80 \\
\hline INDIANA & St. Joseph & 457.89 & 269240 & 1.08 & 3.11 & 0.62 \\
\hline KANSAS & Sedgwick & 997.48 & 512064 & 0.53 & 3.26 & 0.54 \\
\hline KANSAS & Wyandotte & 151.64 & 164345 & 0.59 & 2.70 & 0.92 \\
\hline KENTUCKY & Daviess & 458.39 & 99937 & 0.53 & 3.56 & 0.62 \\
\hline KENTUCKY & Fayette & 283.64 & 318734 & 0.51 & 3.61 & 0.49 \\
\hline KENTUCKY & Jefferson & 380.69 & 767154 & 0.52 & 3.43 & 0.57 \\
\hline LOUISIANA & Acadia & 655.17 & 62568 & 2.80 & 3.66 & 0.92 \\
\hline
\end{tabular}




\begin{tabular}{|l|l|l|l|l|l|l|}
\hline LOUISIANA & Assumption & 338.62 & 22714 & 2.70 & 3.52 & 0.78 \\
\hline LOUISIANA & Bossier & 840.30 & 126131 & 2.57 & 3.46 & 0.59 \\
\hline LOUISIANA & Caddo & 878.83 & 248361 & 2.75 & 3.46 & 0.84 \\
\hline LOUISIANA & Calcasieu & 1064.29 & 200182 & 2.67 & 3.96 & 0.74 \\
\hline LOUISIANA & De Soto & 876.40 & 27216 & 2.78 & 3.78 & 0.89 \\
\hline LOUISIANA & East Baton & 455.34 & 444094 & 2.62 & 3.18 & 0.67 \\
\hline LOUISIANA & Rouge & & & & & \\
\hline LOUISIANA & Iberia & 574.09 & 72691 & 2.84 & 4.21 & 0.96 \\
\hline LOUISIANA & Jefferson & 295.66 & 435300 & 2.59 & 3.15 & 0.61 \\
\hline LOUISIANA & Lafayette & 268.74 & 240091 & 2.59 & 3.68 & 0.62 \\
\hline LOUISIANA & Lafourche & 1068.36 & 98214 & 2.69 & 3.89 & 0.77 \\
\hline LOUISIANA & Orleans & 169.43 & 389648 & 2.68 & 3.11 & 0.74 \\
\hline LOUISIANA & Ouachita & 610.40 & 156075 & 2.76 & 3.71 & 0.85 \\
\hline LOUISIANA & Plaquemines & 780.34 & 23373 & 2.65 & 3.50 & 0.71 \\
\hline LOUISIANA & Rapides & 1320.34 & 131546 & 2.80 & 4.24 & 0.91 \\
\hline
\end{tabular}




\begin{tabular}{|l|l|l|l|l|l|l|}
\hline LOUISIANA & St. Bernard & 377.51 & 45694 & 2.70 & 3.46 & 0.77 \\
\hline LOUISIANA & St. James & 241.54 & 21357 & 2.60 & 3.38 & 0.63 \\
\hline LOUISIANA & $\begin{array}{l}\text { St. John the } \\
\text { Baptist }\end{array}$ & 214.32 & 43446 & 2.68 & 3.26 & 0.75 \\
\hline LOUISIANA & St. Martin & 737.22 & 53752 & 2.71 & 4.11 & 0.78 \\
\hline LOUISIANA & St. Mary & 555.58 & 51734 & 2.80 & 4.38 & 0.92 \\
\hline LOUISIANA & Tangipahoa & 791.31 & 130504 & 2.78 & 3.50 & 0.89 \\
\hline LOUISIANA & Terrebonne & 1229.83 & 112587 & 2.79 & 4.08 & 0.90 \\
\hline LOUISIANA & Washington & 669.53 & 46457 & 2.86 & 3.26 & 1.00 \\
\hline MICHIGAN & Berrien & 567.78 & 154807 & 1.10 & 5.50 & 0.65 \\
\hline MICHIGAN & Genesee & 636.96 & 409361 & 1.11 & 3.91 & 0.66 \\
\hline MICHIGAN & Ingham & 556.13 & 289564 & 1.08 & 4.56 & 0.57 \\
\hline MICHIGAN & Jackson & 701.88 & 158913 & 1.07 & 4.51 & 0.55 \\
\hline MICHIGAN & Kent & 848.05 & 643140 & 1.05 & 4.22 & 0.48 \\
\hline MICHIGAN & Saginaw & 800.47 & 192778 & 1.12 & 4.24 & 0.70 \\
\hline MICHIGAN & Wayne & 611.99 & 1761382 & 1.17 & 3.89 & 0.87 \\
\hline
\end{tabular}




\begin{tabular}{|c|c|c|c|c|c|c|}
\hline MINNESOTA & Ramsey & 152.22 & 541493 & 0.35 & 2.63 & 0.63 \\
\hline NEVADA & Clark & 7891.65 & 2141574 & 0.69 & 2.63 & 0.74 \\
\hline NEVADA & Washoe & 6301.42 & 450486 & 0.65 & 2.84 & 0.53 \\
\hline NEW JERSEY & Atlantic & 555.51 & 268539 & 2.82 & 3.27 & 0.79 \\
\hline NEW JERSEY & Camden & 221.35 & 507367 & 2.69 & 2.91 & 0.61 \\
\hline NEW JERSEY & Essex & 126.08 & 793555 & 2.86 & 2.79 & 0.84 \\
\hline NEW JERSEY & Hudson & 46.19 & 668631 & 2.71 & 2.61 & 0.64 \\
\hline NEW JERSEY & Mercer & 224.43 & 368762 & 2.65 & 2.75 & 0.56 \\
\hline NEW JERSEY & Middlesex & 309.22 & 826698 & 2.59 & 2.83 & 0.47 \\
\hline NEW JERSEY & Passaic & 186.01 & 504041 & 2.81 & 3.20 & 0.78 \\
\hline NEW JERSEY & Union & 102.77 & 553066 & 2.70 & 2.92 & 0.62 \\
\hline NEW MEXICO & Bernalillo & 1161.26 & 677692 & 0.49 & 2.34 & 0.68 \\
\hline NEW MEXICO & San Juan & 5517.20 & 127455 & 0.52 & 2.44 & 0.92 \\
\hline NEW MEXICO & Santa Fe & 1910.10 & 148917 & 0.47 & 2.68 & 0.53 \\
\hline NEW YORK & Broome & 705.82 & 194402 & 4.33 & 2.40 & 0.62 \\
\hline NEW YORK & Oneida & 1212.33 & 230782 & 4.43 & 2.38 & 0.69 \\
\hline
\end{tabular}




\begin{tabular}{|c|c|c|c|c|c|c|}
\hline NEW YORK & $\begin{array}{l}\text { St. } \\
\text { Lawrence }\end{array}$ & 2679.27 & 109558 & 4.49 & 2.67 & 0.75 \\
\hline NEW YORK & Steuben & 1390.55 & 96927 & 4.17 & 2.30 & 0.47 \\
\hline NEW YORK & Sullivan & 968.14 & 75211 & 4.54 & 2.38 & 0.79 \\
\hline $\mathrm{OHIO}$ & Cuyahoga & 457.18 & 1253783 & 0.48 & 2.69 & 0.68 \\
\hline $\mathrm{OHIO}$ & Franklin & 532.41 & 1275333 & 0.46 & 2.55 & 0.51 \\
\hline $\mathrm{OHIO}$ & Hamilton & 405.95 & 812037 & 0.46 & 2.58 & 0.54 \\
\hline $\mathrm{OHIO}$ & Lorain & 491.21 & 306713 & 0.46 & 2.51 & 0.51 \\
\hline $\mathrm{OHIO}$ & Lucas & 340.71 & 432379 & 0.48 & 2.74 & 0.69 \\
\hline $\mathrm{OHIO}$ & Mahoning & 411.51 & 231064 & 0.47 & 2.73 & 0.59 \\
\hline $\mathrm{OHIO}$ & Montgomery & 461.49 & 532034 & 0.48 & 2.64 & 0.67 \\
\hline $\mathrm{OHIO}$ & Trumbull & 618.04 & 201794 & 0.45 & 2.65 & 0.46 \\
\hline OKLAHOMA & Oklahoma & 708.82 & 782051 & 0.53 & 3.59 & 0.68 \\
\hline OKLAHOMA & Tulsa & 570.32 & 642781 & 0.52 & 3.70 & 0.62 \\
\hline OREGON & Marion & 1180.55 & 335553 & 0.44 & 2.48 & 0.85 \\
\hline WASHINGTON & Benton & 1699.98 & 194168 & 0.91 & 4.92 & 0.51 \\
\hline
\end{tabular}




\begin{tabular}{|l|l|l|l|l|l|l|}
\hline WASHINGTON & Grant & 2679.49 & 94860 & 0.99 & 5.79 & 0.85 \\
\hline WASHINGTON & Pierce & 1667.81 & 859840 & 0.90 & 4.86 & 0.49 \\
\hline WASHINGTON & Skagit & 1730.22 & 123907 & 0.91 & 5.71 & 0.54 \\
\hline WASHINGTON & Spokane & 1763.89 & 497875 & 0.90 & 4.92 & 0.48 \\
\hline WASHINGTON & Yakima & 4294.52 & 249325 & 1.01 & 6.31 & 0.93 \\
\hline WISCONSIN & Kenosha & 271.86 & 168330 & 0.61 & 2.78 & 0.51 \\
\hline WISCONSIN & Milwaukee & 241.48 & 954209 & 0.66 & 2.44 & 0.81 \\
\hline
\end{tabular}

